\title{
Unmasking the Hunter: An Exploration of Predatory Publishing
}

Katrina A. Bramstedt, PhD,iii

\begin{abstract}
Authors and their institutions are vulnerable to predatory publishers due to the "publish or perish" research mentality. The author's spam-filtered emails from journals were collected for 90 days and analysed for 8 stylistic components; the journal website was explored for publishing fees, research ethics policies, and physical address; the publisher's physical address was cross-checked in corporate registries for validation; each journal was checked for indexing in Embase ${ }^{\circledR}, \mathrm{MEDLINE}^{\circledR}$, and the Directory of Open Access Journals (DOAJ). One hundred twenty email solicitations were received from 101 journals. Overall, 52 (43.3\%) solicitations were from specialty medical journals (e.g., endocrinology, cardiology, orthopaedics); 23 (19.2\%) were sent from general medicine journals. Flattery (77 emails) and grammar errors (761 total, $\bar{x} 6.3 /$ email) were common. Publication fees ranged from free to USD 5,000, with some journals requiring copyright transfer to the publisher yet charging authors and claiming to be open access. Most journals were found to be based in either India (75.3\%) or Nigeria (17.8\%); however, the physical address noted on the journal website was often deceptive (70.3\%) or undisclosed (13.9\%). Some of the journals had either no research ethics policy $(n=7)$ or a policy that addressed only plagiarism ( $n=16)$. Guidance to detect predatory publishers is provided.
\end{abstract}

\section{Introduction}

Authors and their institutions are vulnerable to predatory publishers due to the "publish or perish"iii mentality of research, as well as promotion and tenure committees. This unhealthy framing is fuel for the predatory publishing industry. As institutions slowly move away from journal impact factor as a key metric for research quality, the door opens even wider for predatory journal publishers because they generally have low or no impact factor. ${ }^{1,2}$ But what is a predatory publisher and how does a researcher identify them?

The term "predatory publisher" was coined by librarian Jeffrey Beall in 2010.3 More specifically, the word "predator" is derived from the Latin word, praedari ("to rob") and researchers are the "prey" (Latin word, praeda, "game hunted"). 4,5 Predatory publishing can be considered a form of robbery because researchers are robbed of a robust publishing opportunity. This is because these journals have lower publishing standards, yet, generally, charge a fee for their service. Researchers are 'hunted' by predatory journals using email solicitations that often contain lures such as flattery and quick processing times. ${ }^{6,7,8}$ The oblique and cunning nature of predatory publishing (i.e., re-directed locations, shoddy calls for papers) has not gone unnoticed. ${ }^{8-12}$ This research adds to this body of work by exploring the publishing standards of a collection of journals as evidenced by their ethics policies, as well as unmasks the true location of these publishers (compared to their advertising). The results shape guidance to researchers and research performing organizations in order to steer them away from predatory publishers.

\section{Methods}

Manuscript solicitations received via email to the author's spam box from 12 Apr 2019 to 12 July 2019 were saved, printed, and sequentially numbered. Each email solicitation was analysed for 8 stylistic components: salutation style (professional/informal/generic/none); flattery; number of spelling errors; number of grammar errors; number of exclamation marks; mismatch to author's domain/skill; repeat solicitation; and hijacked journal name or email.

\footnotetext{
' Luxembourg Agency for Research Integrity (LARI), Esch-sur-Alzette, Luxembourg

ii Bond University Medical Program, Queensland, Australia (Correspondence: txbioethics@yahoo.com)
}

iii The original source of the phrase "publish or perish" is unknown; however, the earliest recorded uses were in the field of sociology as early as 1942 [Wilson, L. The Academic Man: A Study in the Sociology of a Profession. New York: Oxford University Press, 1942. Page 197].

Received: April 2020

Accepted for Publication: May 2020

Published Online: June 2020 
Additionally, the website of each journal was analysed for fees, research ethics policies, and its physical address. The publisher of each journal was cross-checked with the physical address [country] on the website. Website ownership information was searched via https://viewdns.info. Corporate registry databases included the Ministry of Corporate Affairs Government of India (http://www.mca.gov.in/mcafoportal/showCheckCompany Name.do ), the Corporate Affairs Commission Government of Nigeria (http://publicsearch.cac.gov.ng/ComSearch/), and the Integrated Companies Registry Information System of the Government of Hong Kong (https://www.mobilecr.gov.hk/mob/index.jsp). Each journal was checked for indexing in $\mathrm{Embase}^{\circledR}, \mathrm{MEDLINE}^{\circledR}$, and DOAJ. The indexing result was compared to the indexing claim in the email solicitation.

\section{Results}

During the 3-month email collection period, 120 journal solicitations [emails] were received from 101 journals. One email solicitation offered the author 10 journals to select from for publishing. The website for one journal, Overweight, could not be located, thus information about publishing fees and research ethics policies could not be obtained. It is possible that the journal has been discontinued by the Publisher (Austin Info Consultancy Private Limited; India). The total journal count ( $n$ ) for each of these two variables was thus 100, rather than 101.

Table 1 presents the results of the analysis of email components described in the Methods.

Table 1. Email Style Components

\begin{tabular}{|l|l|}
\hline Component & $\begin{array}{l}\text { Result ( } \mathrm{n}=120 \text { emails, 101 } \\
\text { journals) }\end{array}$ \\
\hline Salutation style (P, G, I, N) & $\begin{array}{l}\mathrm{P}=75(62.5 \%) ; \mathrm{G}=24(20 \%) ; \\
\mathrm{I}=7(5.8 \%) ; \mathrm{N}=14(11.7 \%)\end{array}$ \\
\hline Flattery & 77 emails (64.2\%) \\
\hline Spelling errors (\#) & 23 errors (max 2) \\
\hline Grammar errors (\#) & $\begin{array}{l}761 \text { errors (max 18; average } \\
6.3 \text { per email) }\end{array}$ \\
\hline Exclamation marks (\#) & 99 marks (max 4) \\
\hline Domain/Skill mismatch* & $\begin{array}{l}96 \text { (95\%) journals } \\
\text { mismatched }\end{array}$ \\
\hline Repeat solicitation & $\begin{array}{l}28 \text { emails (1 journal sent 5 } \\
\text { repeats) }\end{array}$ \\
\hline
\end{tabular}

P = Professional (e.g., Dear Dr or Dear Professor); I = Informal (e.g., Greetings!); $\mathrm{G}=$ Generic (e.g., name only, no title); $\mathrm{N}=$ None (no name, title, or greeting)

*The author's domain/skill set is organ donation, transplantation, medical education, and bioethics (to include research ethics and clinical ethics)
Flattery comments are email remarks giving praise or exuberant well wishes to the author. For example:

I just wanted to take a moment and write you a long overdue thank you letter for your services to [sic] scientific world. Your previous submission was outstanding and innovates all of us. In [sic] last few years I have known you; you have been an incredible inspiration to me and all the young researchers on how to carry ourselves in this great research world [email 36, SM Journal of Cardiovascular Disorders].

Another example is email 57 from Advancement in Case Studies: "Hope you are having a great day!" "We are confident that you are always will be [sic] there to support us." Note that both texts contain grammar errors (noted by "sic").

Referring to Table 1, 95\% of the journals which solicited the author for publication were out of the author's scope of expertise. Only 5 journals related to the domain that the author works in: 2 education; 2 transplant; 1 clinical ethics. The latter journal was actually focused on hospital administration but their scope specifically included clinical ethics. ${ }^{13}$ There is a small area of clinical ethics that includes discharge planning and staffing, and these areas are crossdisciplinary with hospital administration. Overall, 52 of 120 (43.3\%) solicitations were from specialty medical journals (e.g., endocrinology, cardiology, orthopaedics); 23 of 120 (19.2\%) were sent from general medicine journals. The remaining domains included botany, physiotherapy, nutrition, education, agriculture, forensics, nursing, sports, pharmacy, business and administration.

Table 2 presents the results of analysing the journal's name and sender's email address for similarities to other journal identities. While no email addresses were hijacked, 15 (14.9\%) journals used similar or identical names belonging to other journals indexed in Embase ${ }^{\circledR}, \mathrm{MEDLINE}^{\circledR}$, and/or DOAJ.

All 101 journals were checked for their indexing status in 3 major databases: Embase $^{\circledR}$, MEDLINE $^{\circledR}$, and DOAJ. Only 3 of 101 (3\%) journals were indexed: NeuroQuantology (Embase $\left.{ }^{\circledR}\right)$, Biocell $\left(\right.$ Embase $\left.^{\circledR}\right)$, and Journal of Forensic Research and Criminal Studies (DOAJ). Nine journals (Table 3) made false claims about indexing in their email solicitations.

The article processing charge (APC) varied greatly among the journals (range 0 to USD5000). Six (6\%) journals offer membership packages whereby an author (or institution) pays a lump sum which provides unlimited article publishing for 12 months. Fee waivers are offered by 44 (44\%) journals and $10(10 \%)$ offer discounts. Fees were undisclosed by 23 (23\%) journals. 
Table 2. Journal Hijacking

\begin{tabular}{|c|c|}
\hline Soliciting Journal* & Hijacked Journal \\
\hline $\begin{array}{l}\text { American Journal of Otolaryngology and Head and } \\
\text { Neck Surgery }\end{array}$ & $\begin{array}{l}\text { American Journal of Otolaryngology - Head and Neck Medicine and Surgery } \\
\text { [Embase }{ }^{\circledR} \text {-indexed] }\end{array}$ \\
\hline Anaesthesiology and Pain Medicine & Anesthesiology and Pain Medicine [Embase ${ }^{\circledR}$-indexed] \\
\hline Annals of Transplantation Research & Annals of Transplantation [Embase ${ }^{\circledR}$ and MEDLINE ${ }^{\circledR}$-indexed] \\
\hline Archives of Surgery & Archives of Surgery (now JAMA Surgery) [Embase ${ }^{\circledR}$ and MEDLINE ${ }^{\circledR}$-indexed] \\
\hline Austin Journal of Clinical Medicine & Journal of Clinical Medicine (Embase ${ }^{\circledR}$ and DOAJ-indexed) \\
\hline Austin Journal of Gastroenterology & Journal of Gastroenterology (Embase ${ }^{\circledR}$ and MEDLINE ${ }^{\circledR}$-indexed) \\
\hline Austin Journal of Nutrition and Food Sciences & $\begin{array}{l}\text { International Journal of Food Sciences and Nutrition }\left(\text { Embase }^{\circledR} \text { and MEDLINE }{ }^{\circledR}\right. \\
\text { indexed) }\end{array}$ \\
\hline $\begin{array}{l}\text { Integrative Journal of Orthopaedics and } \\
\text { Traumatology }\end{array}$ & Journal of Orthopaedics and Traumatology [Embase ${ }^{\circledR}, \mathrm{MEDLINE}^{\circledR}, \mathrm{DOAJ}$-indexed \\
\hline International Archives of Internal Medicine & International Archives of Medicine [Embase ${ }^{\circledR}$ and DOAJ-indexed] \\
\hline Journal of Forensic Medicine Forecast & Journal of Forensic Medicine (China) [Embase ${ }^{\circledR}$ and MEDLINE ${ }^{\circledR}$-indexed] \\
\hline Journal of Hospital Administration & Hospital Administration [Embase ${ }^{\circledR}$ and MEDLINE ${ }^{\circledR}$-indexed] \\
\hline Journal of Neurosurgery & Journal of Neurosurgery [MEDLINE ${ }^{\circledR}$-indexed] \\
\hline Matthews Journal of Emergency Medicine & The Journal of Emergency Medicine [Embase ${ }^{\circledR}$ and MEDLINE ${ }^{\circledR}$-indexed] \\
\hline Reproductive Medicine International & Journal of Reproductive Medicine [DOAJ-indexed] \\
\hline Surgical Case Reports & Surgical Case Reports (DOAJ-indexed) \\
\hline
\end{tabular}

*None of these soliciting journals were indexed in Embase ${ }^{\circledR}, \mathrm{MEDLINE}^{\circledR}$, or DOAJ

\section{Table 3. Falsely Claimed Indexing}

\begin{tabular}{|l|l|l|}
\hline Journal & Index Claim & Verified Indexing \\
\hline Global Advanced Research Journal of Agricultural Science & Scopus ${ }^{\circledR}$ DOAJ & Not indexed \\
\hline Academia Journal of Scientific Research & DOAJ & Not indexed \\
\hline Case Reports: Open Access & DOAJ & Not indexed \\
\hline Journal of Cardiology and Vascular Medicine & DOAJ & Not indexed \\
\hline Journal of Neurophysiology and Neurological Disorders & DOAJ & Not indexed \\
\hline Journal of Ophthalmology: Open Access & DOAJ & Not indexed \\
\hline Journal of Pediatrics and Congenital Disorders & DOAJ & Not indexed \\
\hline Annual Research \& Review in Biology & NLM & Not indexed \\
\hline Merit Research Journal of Medicine and Medical Sciences & NLM & Not indexed \\
\hline
\end{tabular}

Referring to Table 4, research ethics concepts (authorship, plagiarism, data integrity, informed consent, ethics committee approval, conflict of interest) were not uniformly addressed by the journals. Seven (7\%) have no relevant policies on their websites (yet one of these journals, Biocell, is indexed in Embase ${ }^{\circledR}$ ). Two (2\%) have only a policy for conflict of interest. Two (2\%) have only a policy for informed consent. Sixteen (16\%) have only a policy for plagiarism. Fourteen (14\%) have policies dealing with two concepts, either plagiarism and informed consent, authorship and informed consent, or plagiarism and conflict of interest. The remaining journals ( $n=59,59 \%)$ claim to abide by the guidance of the International Committee of Medical Journal Editors (ICMJE) or the Committee on
Publication Ethics (COPE), or a combination of 3 or more research ethics topics. ${ }^{14,15}$

Two unusual policies issues were discovered during website review. Merit Research Journals (Nigeria) claims to follow COPE guidelines regarding fabrication, falsification and plagiarism; however, they permit authors to add their supervisor to their manuscript with only his/her permission, rather than requiring the supervisor to satisfy authorship criteria. ${ }^{16-18}$ Another troubling finding was that several publishers claim to be "open access", yet they require the author to transfer copyright to the publisher on top of charging an article publishing fee (Table 5). The term "open access" is generally assumed by authors to allow them to retain copyright of their work, using it freely. ${ }^{19,20}$ 
Referring to Table 6, journal location data was remarkable for its deceptiveness. Only 30 (29.7\%) journals transparently disclosed their true publishing location; journals frequently indicate USA as their location on their website, yet their publisher is actually offshore. Several (14) journals completely hid their publishing location on their website, failing to disclose any address. Most commonly, publishers were found to be based in India (76 journals) or Nigeria (18 journals). Other locations include Hong Kong $(n=2)$, Estonia $(n=2)$, Turkey $(n=1)$, and China $(n=1)$. No publishers were located in USA.

Table 4. Journal Research Ethics Policies

\begin{tabular}{|c|c|}
\hline Policy Focus & Journal \\
\hline Conflict of interest [only] & $\begin{array}{l}\text { Global Scientific Journal of Neurology and Neurophysiology; Psychiatry and Mental } \\
\text { Disorders }\end{array}$ \\
\hline Plagiarism [only] & $\begin{array}{l}\text { Alzheimer's; SM Pediatrics \& Neonatal Biology; SM Sports Medicine \& Therapy; } \\
\text { International Journal of Drug Design and Development; Global Journal of Physiotherapy } \\
\text { and Rehabilitation; SM Journal of Pharmacology and Therapeutics; SM Journal of } \\
\text { Cardiovascular Disorders; Open Access Journal of Environmental and Soil Sciences; } \\
\text { Journal of Alcohol and Drug Abuse; Archives of Surgery; Journal of Surgery and Modern } \\
\text { Techniques; Open Journal of Surgery; Annals of Mental Disorders and Psychiatry; SM } \\
\text { Journal of Endocrinology and Metabolism; Annals of Case Reports; Journal of Surgery } \\
\text { Open Access }\end{array}$ \\
\hline Plagiarism and conflict of interest & Therapeutic Advances in Cardiology \\
\hline Informed consent [only] & Journal of Dermatology Forecast; Journal of Forensic Medicine Forecast \\
\hline Informed consent and plagiarism & $\begin{array}{l}\text { Austin Journal of Nutrition and Food Sciences; Austin Journal of Clinical Medicine; Austin } \\
\text { Journal of Gastroenterology; Journal of Family Medicine; Austin Anthropology; Physical } \\
\text { Medicine and Rehabilitation - International; Austin Sports Medicine; Austin } \\
\text { Neurosurgery: Open Access; Austin Critical Care Journal }\end{array}$ \\
\hline Informed consent and authorship & $\begin{array}{l}\text { American Journal of Otolaryngology and Head and Neck Surgery; Annals of Psychiatry } \\
\text { and Clinical Neuroscience; Global Journal of Emergency Medicine; Clinics in Respiratory } \\
\text { Medicine }\end{array}$ \\
\hline No policy & $\begin{array}{l}\text { Global Advanced Research Journal of Agricultural Science; International Archives of } \\
\text { Nursing and Health Care; Nephrology: Current Research; Reproductive Medicine } \\
\text { International; International Archives of Internal Medicine; Biocell; International Journal of } \\
\text { Depression and Anxiety }\end{array}$ \\
\hline
\end{tabular}

Table 5. Deceptive Open Access Policies

\begin{tabular}{|l|l|l|}
\hline Journal & Location & Access Date \\
\hline $\begin{array}{l}\text { Merit Research Journal of Medicine and Medical } \\
\text { Sciences }\end{array}$ & https://meritresearchjournals.org/copy\%20right\%20form.pdf & 2019 Aug 21 \\
\hline Merit Research Journal of Education and Review & https://meritresearchjournals.org/copy\%20right\%20form.pdf & 2019 Aug 21 \\
\hline Therapeutic Advances in Cardiology & https://scientiaricerca.com/images/Cover-Letter.pdf & 2019 Aug 21 \\
\hline Biocell & http://techscience.com/biocell/body.php?type=manu_script & 2019 Aug 21 \\
\hline
\end{tabular}


Table 6. Journals with Deceptive Publisher Locations

\begin{tabular}{|c|c|c|c|}
\hline Publisher & Journals & $\begin{array}{l}\text { Declared Location } \\
\text { [Website] }\end{array}$ & $\begin{array}{l}\text { Verified } \\
\text { Location }\end{array}$ \\
\hline Academia Publishing House & Academia Journal of Scientific Research & UK, USA & India \\
\hline $\begin{array}{l}\text { ACTA Scientific Publications } \\
\text { (OPC) Private Limited (dba } \\
\text { Scholarena Journals) }\end{array}$ & $\begin{array}{l}\text { Journal of Aging Research and Gerontology Studies; SAJ Case } \\
\text { Reports }\end{array}$ & USA & India \\
\hline Anka Publisher & NeuroQuantology & UK, Singapore & Turkey \\
\hline ARJ Ninecom (dba ARJonline) & ARJ Clinical Case Reports & USA & India \\
\hline $\begin{array}{l}\text { Austin Info Consultancy } \\
\text { Private Limited (dba Austin } \\
\text { Publishing Group) }\end{array}$ & $\begin{array}{l}\text { Austin Journal of Nutrition and Food Sciences; Overweight; } \\
\text { Austin Journal of Clinical Medicine; Austin Journal of } \\
\text { Gastroenterology; Journal of Family Medicine; Austin } \\
\text { Anthropology; Physical Medicine and Rehabilitation - } \\
\text { International; Austin Sports Medicine; Austin Neurosurgery: } \\
\text { Open Access; Austin Critical Care Journal }\end{array}$ & USA, NL & India \\
\hline $\begin{array}{l}\text { Biomedical Research Network } \\
\text { +, LLC (dba Crimson } \\
\text { Publishers; Lupine Publishers) }\end{array}$ & $\begin{array}{l}\text { Surgical Medicine Open Access Journal; Open Access Journal of } \\
\text { Environmental and Soil Sciences; Advancements in Case Studies }\end{array}$ & USA & India \\
\hline $\begin{array}{l}\text { E Science Research (dba } \\
\text { Escires) }\end{array}$ & Nephrology: Current Research & $\begin{array}{l}\text { Trinidad \& } \\
\text { Tobago }\end{array}$ & India \\
\hline Fortune Journals & Archives of Clinical and Medical Case Reports & USA & India \\
\hline $\begin{array}{l}\text { GARJ Publishing Company } \\
\text { Limited }\end{array}$ & Global Advanced Research Journal of Agricultural Science & None & Nigeria \\
\hline $\begin{array}{l}\text { Gavin Publishers Private } \\
\text { Limited }\end{array}$ & Archives of Surgery; Annals of Case Reports & USA, Australia & India \\
\hline $\begin{array}{l}\text { GSL Publications Private } \\
\text { Limited }\end{array}$ & $\begin{array}{l}\text { Global Scientific Journal of Neurology and Neurophysiology; } \\
\text { Psychiatry and Mental Disorders }\end{array}$ & USA & India \\
\hline $\begin{array}{l}\text { Innovationinfo Publishing } \\
\text { Private Limited }\end{array}$ & Anaesthesiology and Pain Medicine & UK & India \\
\hline $\begin{array}{l}\text { International Research } \\
\text { Journals Publishing House }\end{array}$ & $\begin{array}{l}\text { Business and Management Research Journal; Education } \\
\text { Research Journal }\end{array}$ & None & Nigeria \\
\hline $\begin{array}{l}\text { Jscholar Scientific } \\
\text { Communications (OPC) } \\
\text { Private Limited }\end{array}$ & $\begin{array}{l}\text { Case Reports: Open Access; Journal of Forensic Research and } \\
\text { Criminal Studies; Journal of Neurophysiology and Neurological } \\
\text { Disorders; Journal of Pediatrics and Congenital Disorders; } \\
\text { Journal of Cardiology and Vascular Medicine; Journal of } \\
\text { Ophthalmology: Open Access }\end{array}$ & USA & India \\
\hline $\begin{array}{l}\text { Mathews International } \\
\text { Publishers LLP }\end{array}$ & Mathews Journal of Emergency Medicine & USA & India \\
\hline $\begin{array}{l}\text { Medcave Publications Private } \\
\text { Limited (dba Medcave and } \\
\text { ScholarsInsight*) }\end{array}$ & $\begin{array}{l}\text { Medcave Journal of Neurosciences; Journal of Clinical Research } \\
\text { and Medical Reports; Universal Journal of Gastroenterology } \\
\text { Open Access; Medcave Journal of Surgery Open Access; Journal } \\
\text { of Surgery Open Access; Annals of Mental Disorders and } \\
\text { Psychiatry }\end{array}$ & USA & India \\
\hline Merit Research Journals & $\begin{array}{l}\text { Merit Research Journal of Medicine and Medical Sciences; Merit } \\
\text { Research Journal of Education and Review }\end{array}$ & None & Nigeria \\
\hline Onomy Publishing Group & Scientific Journal of Dermatology and Venereology & USA & India \\
\hline $\begin{array}{l}\text { Raft IT and Publications } \\
\text { Private Limited }\end{array}$ & Global Journal of Physiotherapy and Rehabilitation & USA & India \\
\hline $\begin{array}{l}\text { Redelve International } \\
\text { Publications Private Limited }\end{array}$ & Journal of Surgery and Modern Techniques & USA & India \\
\hline Research Wallet (dba OAText) & Trauma \& Emergency Care; Clinical and Medical Reports & UK & India \\
\hline Sciaeon Open Access Limited & Bone and Muscle & None & India \\
\hline
\end{tabular}




\begin{tabular}{|c|c|c|c|}
\hline Science Forecast Open Access & $\begin{array}{l}\text { Journal of Dermatology Forecast; Journal of Forensic Medicine } \\
\text { Forecast }\end{array}$ & USA & India \\
\hline $\begin{array}{l}\text { Science Resource Online } \\
\text { [Scientific Pages] (dba as } \\
\text { Scholarly Pages) }\end{array}$ & Journal of Transplant Surgery & USA & India \\
\hline $\begin{array}{l}\text { Science Way Online Private } \\
\text { Limited }\end{array}$ & $\begin{array}{l}\text { International Archives of Nursing and Health Care; Reproductive } \\
\text { Medicine International; International Archives of Internal } \\
\text { Medicine; International Journal of Depression and Anxiety }\end{array}$ & USA & India \\
\hline $\begin{array}{l}\text { Scienhns Scientific Solutions } \\
\text { Private Limited (dba JSM } \\
\text { Central) }\end{array}$ & JSM Forensic Research and Analysis & None & India \\
\hline $\begin{array}{l}\text { Scientiaricerca Journals (opc) } \\
\text { Private Limited }\end{array}$ & Therapeutic Advances in Cardiology & USA & India \\
\hline $\begin{array}{l}\text { SM Online Publishers (dba SM } \\
\text { Journals) }\end{array}$ & $\begin{array}{l}\text { SM Pediatrics \& Neonatal Biology; SM Sports Medicine \& } \\
\text { Therapy; International Journal of Drug Design and Development; } \\
\text { SM Journal of Pharmacology and Therapeutics; SM Journal of } \\
\text { Cardiovascular Disorders; Journal of Alcohol and Drug Abuse; } \\
\text { SM Journal of Endocrinology and Metabolism }\end{array}$ & None & India \\
\hline $\begin{array}{l}\text { Syntax Publishers Private } \\
\text { Limited (dba SciResLit) }\end{array}$ & Open Journal of Surgery & USA & India \\
\hline United Prime Publications & Journal of Clinical and Medical Images & USA & India \\
\hline $\begin{array}{l}\text { Yorkone Limited (dba } \\
\text { ScieduPress) }\end{array}$ & Journal of Hospital Administration & Canada & Hong Kong \\
\hline $\begin{array}{l}\text { Zurno Desk Services Private } \\
\text { Limited (dba Research Open } \\
\text { World) }\end{array}$ & Integrative Journal of Orthopaedics and Traumatology & UK & India \\
\hline Unknownt & Clinics Surgery & USA & India \\
\hline $\begin{array}{l}\text { Unknown } \neq \text { (dba BiomedGrid, } \\
\text { LLC) }\end{array}$ & American Journal of Biomedical Science \& Research & USA & India \\
\hline
\end{tabular}

$\mathrm{dba}=$ does business as

* Medcave and ScholarsInsight have the same USA business address: 12600 Hill Country Boulevard, Suite R-275, Bee Cave, Texas. This is a virtual office space, https://www.regus.com/offices/united-states/texas/bee-cave/office-space/texas-bee-cave-hill-country-galleria, accessed 2019 Aug 21.

+ Unable to trace publisher; however, the journal's website domain, https://www.clinicssurgery.org is registered in India. Verification https://viewdns.info/whois/?domain=clinicssurgery.org, accessed 2019 Aug 21.

‡ Unable to trace publisher; however, the journal's email solicitation is nearly identical to the email solicitation from Open Access Journal of Environmental and Soil Sciences (Lupine Publishers [India].)

\section{Discussion}

While it's not surprising that journal email solicitations that are poorly written (i.e., grammar and spelling errors) would logically be a red flag of warning to most researchers, professional writing style can still disguise a low-quality journal, thus researchers and research performing organizations need guidance (Table 7). Databases are often viewed as a marker of journal quality (due to indexing criteria), and some are repositories for citations, abstracts, and even full-text articles. ${ }^{21-23}$ Now, in the era of open access, databases are less relevant. This is because open

iv Data on file with the author. access articles can easily be found by a Google search. This means that articles are readily compiled by Google Scholar-a search engine which is often termed an "indexing database" by predatory journals. iv Notably, archiving full text articles in PubMed Central (PMC) is not the same as MEDLINE ${ }^{\circledR}$-indexing of a journal. PMC is an article repository for open access manuscripts. ${ }^{24}$ MEDLINE ${ }^{\circledR}$ is a database which indexes journals which have undergone a rigorous selection process by the National Library of Medicine (NLM). ${ }^{21}$ Journals which solicit researchers by way of PMC-indexing should be red-flagged as predatory because PMC is not an index (Table 7). If an author archives 


\section{Table 7. Guidance for Detecting Predatory Journals}

\begin{tabular}{|c|l|}
\hline 1 & $\begin{array}{l}\text { Journal claims indexing in false databases:* e.g., PubMed } \\
\text { Central (PMC), WorldCat }^{\circledR}, \text { Google Scholar, ResearchGate, } \\
\text { doi }^{\circledR}, \text { ISSN† }\end{array}$ \\
\hline 2 & $\begin{array}{l}\text { Journal claims indexing in databases which lack rigorous } \\
\text { quality criteria such as peer review process, suitable } \\
\text { Editorial Board, and research ethics policies: e.g., } \\
\text { Directory of Research Journals Indexing, CiteFactor }\end{array}$ \\
\hline 3 & Journal claims indexing falsely (unverified) \\
\hline 4 & $\begin{array}{l}\text { Journal does not disclose its location, or discloses a false } \\
\text { location (such as a personal residence or virtual office) }\end{array}$ \\
\hline 5 & $\begin{array}{l}\text { Journal charges publication fees with the lure of "open } \\
\text { access" but the journal retains copyright }\end{array}$ \\
\hline 6 & $\begin{array}{l}\text { Journal lacks policies regarding plagiarism, data integrity, } \\
\text { authorship, informed consent, research ethics committee } \\
\text { approval, and conflicts of interest. }\end{array}$ \\
\hline 7 & $\begin{array}{l}\text { Journal lacks a robust peer review process (including } \\
\text { Journal Editorial Board members aligned with the scope } \\
\text { of the journal) }\end{array}$ \\
\hline 8 & $\begin{array}{l}\text { Journal claims an impact factor not aligning with the } \\
\text { standard, Journal Citation Reportsł }\end{array}$ \\
\hline 9 & $\begin{array}{l}\text { Manuscript solicitations are unprofessional (e.g., spelling } \\
\text { and grammar errors, laughable flattery, mismatched skill } \\
\text { set/domain request }\end{array}$ \\
\hline
\end{tabular}

* These are not journal indexing databases

† International Standard Serial Number

‡ See reference 2

his/her manuscript in PMC, the manuscript's journal does not automatically become indexed in MEDLINE ${ }^{\circledR}$. Because of their quality selection criteria, database indexes should still be viewed as a marker of journal quality and researchers should take care that journals are using this branding legitimately.

This raises concern about the journal, Biocell, which was noted to have no research ethics policies on its website; however, the journal is indexed in Embase ${ }^{\circledR}$. Also, this journal was one of several that claimed to be open access, charges a publishing fee, and yet retains copyright (rather than allowing the author to have copyright of his/her manuscript). It is noted that Biocell recently switched to a new publisher (Tech Science Press; China) and the Embase ${ }^{\circledR}$ indexing occurred via their prior publisher (Centro Regional de Investigaciones Científicas y Transferencia Tecnológica; Argentina) with enhanced publishing criteria. Biocell is now at risk of losing their Embase ${ }^{\circledR}$-indexing status due to the low-quality publishing requirements of the Chinese publisher.

With regard to restrictive open access policies, these may be a surprise to researchers after they pay article publication fees. Discovering later that they have lost copyright to the journal (in the setting of "open access") could be an event that might have permanent harm, for example, fees not refundable, article not withdrawable, copyright rights not negotiable. Authors need to read and understand the "copyright form" being signed as a condition of publication. Publishers need to be fully transparent about their copyright policies, especially when they conflict with the norms of open access. ${ }^{20}$ From an ethics perspective, authors should retain copyright of their open access works, especially if they are paying open access publishing fees.

Open access is making journal impact factor less important because organizations are beginning to view the latter as a lower priority. ${ }^{1}$ There is one accepted standard for impact factor; however, journals can easily create a fake ranking or reference a "spurious number" that is not actually the accepted standard formulation. ${ }^{2,25}$ Also, it is important to note that some high-quality journals lack an impact factor or have a low impact factor. If the journal is not open access and not indexed in a variety of databases its manuscripts will be difficult to find and thus more difficult to cite - and citation is a key variable to the impact factor formula.

Researchers must be wary of journals who flout "DOI" and "ISSN" as numbers which equate to indexing or impact as this is another red flag marker of predatory journals. DOI (Digital Object Identifier) is a number assigned to an item of intellectual property so it can be shared. ${ }^{26}$ ISSN (International Standard Serial Number) is a number assigned to an electronic publication such as a journal or newspaper. ${ }^{27}$ Neither DOI nor ISSN have ethics or quality criteria associated with them, rather they are administrative purchases for the purpose of assigning an identity.

If the journal has robust publishing policies and is not indexed in one or more of the standard databases, this does not diminish its quality. A robust peer review process is a component of a high-quality journal (item 7, Table 7). Peer review procedures rely on a high-quality Editorial Board who generally screens (internal review) and administratively manages manuscripts, as well as identifies external peer reviewers. If the membership of the Editorial Board of the journal is not aligned to the scope of the journal, the members cannot effectively carry out those duties because they lack the foundational knowledge in the research domain area (e.g., nursing, education, medicine, dentistry, physics, economics) for screening the paper, selecting peer reviewers, and analysing the reviewer feedback. The peer review process should not be a series of simple yes/no checkboxes; rather, reviewers should be required to give a thoughtful narrative critique of the manuscript, its suitability for the journal, and its adherence to ethical requirements.

Unique to this research paper was the exploration of the research ethics policies of email soliciting journals (item 6, Table 7). A journal publisher which fails to consider the 
ethical issues of publishing is prioritizing profit, rather than research quality. This is because the exclusion of ethical considerations makes processing of articles faster, creating a potentially larger throughput, and more income stream for the journal. Screening articles for plagiarism and image manipulation requires expensive software and adds time to article processing. Reviewing conflict of interest disclosures is a manual process that also adds time. Avoiding authorship rules and allowing anyone to be an author who agrees to be an author also simplifies matters (until there is an allegation of research misconduct, then authors sometimes attempt to "jump ship" and have their names removed from publications). ${ }^{28}$

The mere fact that a journal is published in India or Nigeria does not automatically render it a predatory or low-quality journal, but it is interesting to discover the extent to which Indian and Nigerian journals hide their nationality with deceptive techniques (i.e., fake address; no address disclosed). ${ }^{29}$ Fake branding as a USA journal does not add quality, especially if the journal solicits with unprofessionalism (e.g., spelling and grammar errors; laughable flattery), uses an Editorial Board with inappropriate membership, and/or lacks research ethics policies. The Journal of Vector Borne Diseases (published in India) and Nigerian Journal of Clinical Practice (published in Nigeria), are both MEDLINE $^{\circledR}$-indexed, have appropriate Editorial Boards, accurately disclose their contact details, and display several research ethics policies on their websites. These attributes align with robust, rather than predatory, journals.

In conclusion, this study identified 101 journals using email to solicit manuscript submissions. Only 3 of 101 journals were truly indexed, yet all 3 journals are redflagged for avoidance: Biocell has no published ethics policies, a problematic copyright policy, frequent email grammar problems, and sent repeated solicitation requests (5 in 3 months). The email solicitation from Journal of Forensic Research and Criminal Studies contained 15 grammar errors, including misspelling the name of the journal in their email, used flattery as a lure, and their website stated their journal was from USA when in fact it is published in India. The email solicitation from NeuroQuantology contained 5 grammar errors, 1 spelling error, and their website said their journal was based in the UK and Singapore when in fact it is published in Turkey.

On the contrary, Journal of Hospital Management and Health Policy appears to be a quality journal. Their email solicitation contained no flattery lures, no spelling errors, only 1 grammar error, and their website truthfully disclosed the location of their publisher (Hong Kong). This journal is peer-reviewed, open access with no publishing fees, and numerous ethics policies are posted on their website. Also, the Editorial Board is appropriate but the journal is not indexed in either DOAJ, Embase ${ }^{\circledR}$, or MEDLINE ${ }^{\circledR}$. The journal's website indicates the journal is indexed in Google Scholar; however, Google Scholar is not a journal indexing service rather it is a search engine. This one finding, alone, does not render the journal "predatory." Similarly, the email solicitation from African Journal of Engineering Research contained no flattery lures, no grammar errors, only 1 spelling error, is open access with a low publishing fee (USD400), and its website truthfully discloses its publishing location as Nigeria. The journal is not indexed in either DOAJ, Embase ${ }^{\circledR}$, or MEDLINE ${ }^{\circledR}$; however, it is peer-reviewed, the Editorial Board membership is appropriate in scope, and the journal states they adhere to COPE publishing ethics guidelines. ${ }^{15}$ The journal has not updated its statistical information as it states its h-index as 4 when it is actually 6; their Directory of Research Journals Indexing status is not accurate; and their Google Scholar h-index and Impact Factor are incorrect. Aside from these 2 journals, the remaining 98 all contained multiple problematic features that deem them predatory (Table 7).

In addition to not publishing in predatory journals, researchers should also not participate as Editorial Board Members of such journals. Participating as either a researcher or Board Member can damage the integrity of the researchers as well as his/her institution. Researchers should work with their staff librarian to help locate suitable journals for their manuscripts, and assist them with identifying funding for publishing costs as needed. Ideally, publishing costs will be paid by research funders; however, when research is un-funded, the researcher's employer should pay these costs via dedicated annual budgets for open access publishing. For researchers who are selfemployed, publishers should be flexible in granting waivers so that researchers are not impeded from publishing.

\section{Public Interest Statement}

Publication of robust research is a critical form of resource stewardship. Predatory publishers violate the concepts of "robust research" and "resource stewardship" because they elevate their own profits over the quality of the research they disseminate. By avoiding knowledge-aligned Editorial Boards and rigorous peer review, predatory publishers can lure researchers with fast publishing timelines - a quick method to stock their research profile. The end result can potentially flood the scientific and lay community with lowquality research articles that could even be harmful (e.g., inappropriate clinical decision-making; inaccurate scientific foundations for subsequent research). ${ }^{30}$ Awareness and deterrents are needed to prevent researchers from becoming prey to predatory publishers. ${ }^{31}$ 
Acknowledgements: Some of the data for this paper was presented at a seminar at Bond University (QLD, Australia) on October 8, 2019 under the same title as this paper.

Disclosure: None.

\section{References:}

1. Kwok R. Research Impact: Altmetrics Make Their Mark. Nature 2013;500(7463):491-493.

2. Annual Reviews. Annual Reviews Rankings in Journal Citation Reports (Clarivate Analytics) [Internet]. Palo Alto, CA: Annual Reviews; [cited 2019 Aug 19]. Available from: https://www.annualreviews.org/about/impact-factors

3. Beall J. "Predatory" Open-Access Scholarly Publishers. The Charleston Advisor 2010;15(4):10-17.

4. Harper D. Predator [Internet]. Online Etymology Dictionary; [cited 2019 Aug 19]. Available from: https://www.etymonline.com/word/predator\#tetymonline v 30394

5. Harper D. Prey [Internet]. Online Etymology Dictionary; [cited 2019 Aug 19]. Available from: https://www.etymonline.com/search?q=prey

6. Beall J. Writer's Forum - Predatory journals, peer review, and education research. New Horiz Adult Educ Hum Resource Dev 2017;29(1):54-58.

7. Clemons M, Silva MDCE, Joy AA, Cobey KD, Mazzarello S, Stober C, Hutton B. Predatory Invitations from Journals: More Than Just a Nuisance? Oncologist 2017;22:236-240.

8. Lewinsky AA, Oermann MH. Characteristics of E-Mail Solicitations from Predatory Nursing Journals and Publishers. J Cont Educ Nurs 2018;49(4):171-177.

9. Mercier E, Tardif P-A, Moore L, Sage NL, Cameron PA. Invitations received from potential predatory publishers and fraudulent conferences: a 12-month early-career researcher experience. Postgrad Med J 2018;94:104-108.

10. Ball S, Kopel J, Alexander R, Nugent K. Solicitation for article submission by electronic journals. Proceedings (Baylor Univ Med Center) 2018;31(4):443-446.

11. Erdağ TK. Boring emails: "You are invited to submit a manuscript for ..." Turk Arch Otorhinolaryngol 2018;56(4):185-187.

12. Bolshete P. Analysis of Thirteen Predatory Publishers: A Trap for Eager-To-Publish Researchers. Curr Med Res Opin 2018;34(1):157-162.

13. Journal of Hospital Administration. Home Page [Internet]. Hong Kong: Yorkone Limited; [cited 2019 July 20]. Available from: http://www.sciedupress.com/journal/index.php/jha

14. International Committee of Medical Journal Editors. Recommendations [Internet]. Annals of Internal Medicine / American College of Physicians; [cited 2019 Aug 20]. Available from: http://www.icmje.org/recommendations
15. Committee on Publication Ethics. Guidelines [Internet]. UK: COPE; [cited 2019 Aug 21]. Available from: https://publicationethics.org/guidance/Guidelines

16. Merit Research Journals of Medicine and Medical Sciences. About MRJMMS [Internet]. Sapele, Nigeria: Merit Research Journals; [cited 2019 Aug 21]. Available from: https://meritresearchjournals.org/mms/about us.htm

17. Merit Research Journals. Writing a Scientific Research Article [Internet]. Sapele, Nigeria: Merit Research Journals; [cited 2019 Aug 21]. Available from:

https://meritresearchjournals.org/scientific article.htm

18. Committee on Publication Ethics. What to do if you suspect ghost, guest or gift authorship [Internet]. UK: COPE; [cited 2019 Aug 21]. Available from: https://publicationethics.org/files/Ghost.pdf

19. Suber P. Open Access Overview [Internet]. Boston, MA: Earlham College; 2004 June 21; [updated 2015 Dec 5; cited 2019 Aug 22]. Available from:

http://legacy.earlham.edu/ peters/fos/overview.htm

20. Creative Commons. Open Access [Internet]. Mountain View, CA: Creative Commons; [cited 2019 Aug 22]. Available from: https://creativecommons.org/about/program-areas/openaccess

21. National Library of Medicine. Fact Sheet MEDLINE Journal Selection [Internet]. Bethesda, MD: U.S. National Library of Medicine; 2019 Dec 2 [cited 2019 Dec 20]. Available from: https://www.nlm.nih.gov/Istrc/jsel.html

22. Elsevier. Embase Journal Selection Procedures [Internet]. The Netherlands: Elsevier; [cited 2019 Aug 22]. Available from: https://www.elsevier.com/solutions/embasebiomedical-research/journal-title-suggestion

23. Directory of Open Access Journals. Journal Application Form [Internet]; [cited 2019 Aug 22]. Available from: https://doaj.org/application/new

24. National Library of Medicine. Author Manuscripts in PMC [Internet]. Bethesda, MD: National Center for Biotechnology Infortmation, U.S. National Library of Medicine; [cited 2019 Aug 20]. Available from: https://www.ncbi.nlm.nih.gov/pmc/about/authorms

25. Gutierrez FRS, Beall J, Forero DA. Spurious alternative impact factors: The scale of the problem from an academic perspective. Bioessays 2015;37(5):474-476.

26. International DOI Foundation. Frequently Asked Questions about the $\mathrm{DOI}^{\circledR}$ System [Internet]. DOI; 2019 May 20; [updated 2019 May 20; cited 2019 Aug 22]. Available from: https://www.doi.org/faq.html 
27. International Standard Serial Number International Centre. What is an ISSN? [Internet]. Paris, France: ISSN; [cited 2019 Aug 22]. Available from:

https://www.issn.org/understanding-the-issn/what-is-anissn/

28. Department of Error. Lancet 2016;387(10022):944.

29. Bohannon J. Who's afraid of peer review? Nature 2013;342(6154):60-65.

30. Gillis A. The Rise of Junk Science: Fake publications are corrupting the world of research - and influencing real news [Internet]. Toronto, ON: The Walrus; 2019 May 27; [cited 2020 May 25]. Available from: https://thewalrus.ca/the-riseof-junk-science/

31. Grudniewicz A, Moher D, Cobey KD et al. Predatory journals: no definition, no defence. Nature 2019;576;210-212. 